\title{
Assessing the Impact of Prompt Corrective Action on Bank Capital and Risk
}

Raj A ggarwal and K evin T. J acques

In December 1991, the U.S. Congress passed the Federal Deposit Insurance Corporation Improvement Act (FDICIA), which emphasized the importance of capital ratios in addressing the problems that led to the large number of bank and thrift failures in the 1980s. In addressing these issues, FDICIA contained two key provisions designed to reduce the cost and frequency of failed banks. First, FDICIA contained a provision for early closure of institutions that allowed bank regulators to close failing institutions at a positive level of capital. Such an early closure policy had been advocated as a solution to excessive losses to the deposit insurance fund, as discussed by $K$ ane (1983). The second key provision of FDICIA, prompt corrective action (PCA), involved early intervention in problem banks by bank regulators. W hile PCA was intended to supplement the existing supervisory authority of bank regulators, FDICIA legislated mandatory intervention, rather than regulatory discretion, in undercapitalized institutions in an effort to save banks from becoming insolvent.

To date, the PCA provisions of FDICIA appear to have been a major success in improving the safety and

$R$ aj $A$ ggarwal is the Edward J , and Louise E. M ellen Chair and Professor of $F$ inancein the $D$ epartment of $E$ conomics and $F$ inance at I ohn $C$ arroll $U$ niversity. $K$ evin $T$. J a cques is a senior financial economist at the Office of the Comptroller of the Currency. soundness of the U.S. banking system. Failures declined precipitously in the years following the passage of FDICIA, while a casual observation of bank capital ratios and levels suggests that PCA has been successful in getting banks to increase capital. From year-end 1991 through year-end 1993, equity capital held by U.S. commercial banks in the aggregate increased by over $\$ 65$ billion, an increase of 28.0 percent, while the ratio of equity capital to assets increased from 6.75 percent to 8.01 percent.

W hile the adoption and implementation of PCA has focused attention on bank capital ratios, two issues merit further attention. First, did PCA cause banks to increase their capital ratios, or is the increase attributable to some other factor such as bank income levels in the early 1990s? Second, a number of theoretical and empirical studies suggest that increasingly stringent regulatory capital standards in general, and PCA in particular, may have the unintended effect of causing banks to increase their level of portfolio risk.

This paper examines the impact that the PCA standards had on bank portfolios following the passage of FDICIA in 1991. To do this, the simultaneous equations model developed by Shrieves and Dahl (1992), and later modified by J acques and $\mathrm{N}$ igro (1997) to study the impact of risk-based capital, is used to examine how PCA simultaneously influenced bank capital ratios and portfolio risk 
levels. U nlike prior studies on this topic, by using a simultaneous equations model, the endogeneity of both capital and portfolio risk is explicitly recognized, and as such, the impact of possible changes in bank capital ratios on risk in a bank's portfolio can be examined.

The Prompt Corrective Action Standards In December 1991, the U.S. Congress passed FDICIA, with the PCA provisions becoming effective in December 1992. Specifically, Section 131 of FDICIA, defined for banks five capital thresholds used to determine what supervisory actions would be taken by bank regulators, with increasingly severe restrictions being applied to banks as their capital ratios declined. As shown in Table 1, banks are classified into one of five capital categories depending on how well they meet capital thresholds based on their total risk-based capital ratio, Tier 1 risk-based capital ratio, and Tier 1 leverage ratio. ${ }^{1}$ For example, in order to be classified as well capitalized, a bank must have a total risk-based capital ratio greater than or equal to 10 percent, a Tier 1 risk-based capital ratio greater than or equal to 6 percent, and a Tier 1 leverage ratio greater than 5 percent, while adequately capitalized institutions have minimum thresholds of 8 percent,

Table 1

CAPITAL THRESH OLDSAND BANK CLASSIFICATION UNDER PROMPT CORRECTIVE ACTION

\begin{tabular}{lccc} 
Capital Threshold & $\begin{array}{c}\text { Total Risk- } \\
\text { Based Capital }\end{array}$ & $\begin{array}{c}\text { Tier 1 Risk- } \\
\text { Based Ratio }\end{array}$ & $\begin{array}{c}\text { Tier 1 } \\
\text { LeverageR atio }\end{array}$ \\
\hline W ell capital ized & $\geq 10 \%$ & $\geq 6 \%$ & $\geq 5 \%$ \\
A dequately capital ized & $\geq 8 \%$ & $\geq 4 \%$ & $\geq 4 \%$ \\
Undercapitalized & $<8 \%$ & $<4 \%$ & $<4 \%$ \\
Significantly undercapital ized & $<6 \%$ & $<3 \%$ & $<3 \%$ \\
Critically undercapital ized & & Tangible equity $\leq 2 \%$ & \\
& & & \\
N UM BER OF BAN K S AN D PERCEN TAGE & & \\
OF TOTAL BAN K A SSETS BY PCA ZON E & & \\
PCA Zone & 1991 & 1992 & 1993 \\
\hline W ell capitalized & 10,725 & 10,989 & 10,752 \\
& 43.30 & 87.51 & 96.24 \\
A dequately capital ized & 807 & 335 & 171 \\
& 45.82 & 11.72 & 3.51 \\
Undercapitalized & 221 & 67 & 22 \\
& 10.17 & 0.29 & 0.11 \\
Significantly undercapital ized & 71 & 33 & 16 \\
& 0.39 & 0.17 & 0.12 \\
Critically undercapital ized & 96 & 42 & 10 \\
& 0.32 & 0.32 & 0.03 \\
\hline
\end{tabular}

Source: Data are from the 0 ffice of the Comptroller of the Currency.
4 percent, and 4 percent, respectively. If a bank falls into one of the three undercapitalized categories, mandatory restrictions are placed on its activities that become increasingly severe as the bank's capital ratios deteriorate. For example, undercapitalized banks are subject to restrictions that include the need to submit and implement a capital restoration plan, limits on asset growth, and restrictions on new lines of business, while significantly undercapitalized banks face all of the restrictions imposed on undercapitalized banks, as well as restrictions on interest rates paid on deposits, limits on transactions with affiliates and affiliated banks, and others. Finally, once a bank's tangible equity ratio falls to 2 percent or less, the bank is considered to be critically undercapitalized and faces not only more stringent restrictions on activities, but al so the appointment of a conservator (receiver) within ninety days of becoming critically undercapitalized. ${ }^{2}$

Table 1 al so shows the break down of insured commercial banks by PCA zone over the period 1991-93. For example, at year-end 1991, the time when FDICIA was passed, 10,725 banks, accounting for only 43.3 percent of the total assets in the U.S. banking system, were classified as well capitalized. In contrast, 221, 71, and 96 banks were classified as either undercapitalized, significantly undercapitalized, and critically undercapitalized, respectively. In total, 388 banks with 10.88 percent of all bank assets were undercapitalized to some degree at the end of 1991 and therefore faced at least some degree of regulatory sanction if their capital ratios did not improve by the time PCA went into effect.

By year-end 1992, the period after PCA provisions were announced but before they went into effect, the results in Table 1 show that well-capitalized banks numbered 10,989, accounting for over 87 percent of all bank assets, while all types of undercapitalized banks fell to only 142 , thus accounting for less than 1 percent of total bank assets. A similar but less dramatic shift is seen in 1993, the first year the PCA regulations were in effect. By year-end 1993, 96.24 percent of banking assets were in banks classified as well capitalized, while only forty-eight banks were classified in the three undercapitalized zones, and those banks accounted for less than 0.25 percent of all banking 
assets. These findings suggest that PCA had a significant announcement effect on bank capital ratios during 1992, as well as a significant implementation effect on capital ratios once the standards were implemented.

W hile PCA appears to have been effective in getting banks to increase their capital ratios, it has not been without its critics. ${ }^{3}$ One criticism that has been levied against regulatory capital standards in general is that they may lead to increasing levels of bank portfolio risk. Research by K ahane (1977), K oehn and Santomero (1980), and Kim and Santomero (1988) has shown, using the mean-variance framework, that regulatory capital standards cause leverage and risk to become substitutes and that as regulators require banks to meet more stringent capital standards, banks respond by choosing assets with greater risk. ${ }^{4}$ Thus, increases in minimum capital standards by bank regulators cause banks to increase not only their capital ratios, but also have the unintended effect of causing them to increase their level of risk.

W hile one of the primary purposes of early closure is to prevent banks from taking increasing levels of risk as they approach insolvency, recent research by Levonian (1991) and Davies and M CM anus (1991) demonstrates that early closure may fail to protect the deposit insurance fund from losses because it creates incentives for banks to increase portfolio risk by increasing their holdings of highrisk assets. As such, the design of the PCA standards has important implications not only for capital levels, but also for the level of risk, and ultimately, the safety and soundness of the banking system.

\section{MODEL SPECIFICATION}

To examine the possible impact of the PCA standards on bank capital ratios and portfolio risk levels, the simultaneous equation model developed by Shrieves and Dahl (1992) is modified to incorporate the PCA zones. In their model, observed changes in bank capital ratios and portfolio risk levels are decomposed into two components, a discretionary adjustment and a change caused by an exogenously determined random shock such that:

$$
\Delta C A P_{j, t}=\Delta^{d} C A P_{j, t}+E_{j, t} \text {; }
$$

$$
\Delta R\left|S K_{j, t}=\Delta^{d} R\right| S K_{j, t}+U_{j, t^{\prime}}
$$

where $\Delta C A P_{j, t}$ and $\Delta R I S K_{j, t}$ are the observed changes in capital ratios and risk levels for bank $j$ in period t, $\Delta^{\mathrm{d}} \mathrm{CAP} \mathrm{P}_{\mathrm{j}, \mathrm{t}}$ and $\Delta^{\mathrm{d}} \mathrm{R} / \mathrm{SK} \mathrm{j}_{\mathrm{j}, \mathrm{t}}$ represent the discretionary adjustments in capital ratios and risk levels, and $E_{j, t}$ and $U_{j, t}$ are exogenous shocks. Recognizing that banks may not be able to adjust to their desired capital ratios and risk levels instantaneously, the discretionary changes in capital and risk are modeled using the partial adjustment frame work. As a result:

$$
\begin{aligned}
& \Delta C A P_{j, t}=\alpha\left(C A P_{j, t}^{*}-C A P_{j, t-1}\right)+E_{j, t} ; \\
& \Delta R \mid S K_{j, t}=\beta\left(R\left|S K_{j, t}^{*}-R\right| S K_{j, t-1}\right)+U_{j, t} .
\end{aligned}
$$

Thus, the observed changes in bank capital ratios and portfolio risk levels in period $t$ are a function of the target capital ratio $C A P_{j, t}^{*}$ and target risk level $\Delta R I S K_{j, t}^{*}$, the lagged capital ratio $\mathrm{CAP}_{\mathrm{t}-1}$ and risk levels $\mathrm{R}_{\mathrm{SSK}} \mathrm{t}_{-1}$, and any random shocks. The target capital ratio and risk level are not observable, but are assumed to depend upon some set of observable variables including the size of the bank (SIZE), multibank holding company status ( $\mathrm{BHC}$ ), a bank's income $(I N C)$, changes in portfolio risk $\left(\Delta R \mid S K_{j, t}\right)$, and capital ratios $\left(\Delta C A P_{j, t}\right)$, while the exogenous shock that could affect bank capital ratios or risk levels is the regulatory pressure brought about by PCA.

Specifically, SIZE is measured as the natural log of total assets and BHC is a dummy variable equal to 1 if a bank is affiliated with a multibank holding company. As Shrieves and Dahl (1992) note, size may have an impact on a bank's capital ratios and level of portfolio risk because larger banks have greater access to capital markets. For banks belonging to multibank holding companies, both capital and portfolio risk may be managed at the holding company level, thus resulting in these banks having lower target capital ratios and higher target portfolio risk levels than independent banks. Following Jacques and Nigro (1997), the ratio of net income to total assets, IN C, is included to recognize the ability of profitable banks to increase their capital ratios by using retained earnings. In addition, as noted by the use of the partial adjustment 
model, lagged capital ratios and risk levels are included to measure the fact that banks adjust their capital ratios and risk levels to their target levels over time.

To recognize the possible simultaneous relationship between capital and risk, $\Delta C A P_{j, t}$ and $\Delta R I S K_{j, t}$ are included in the risk and capital equations, respectively. Shrieves and Dahl (1992) note that a positive relationship between changes in capital and risk may signify, among other possibilities, the unintended impact of minimum regulatory capital requirements, while J acques and $\mathrm{N}$ igro (1997) note that a negative relationship may result because of methodological flaws in the capital standards underlying PCA. ${ }^{5}$ Empirical estimation of the simultaneous equations model requires measures of both bank capital ratios and portfolio risk. Following previous research, portfolio risk was measured in two ways, using both the total riskweighted assets as a percentage of total assets (RWARAT) and nonperforming loans as a percentage of total assets (N ON P). ${ }^{6}$ Avery and Berger (1991) have shown that RWARAT correlates with risky behavior, while other studies, such as those by Berger (1995) and Shrieves and Dahl (1992), use nonperforming loans. W ith respect to capital, the leverage ratio is used because Baer and McElravey (1992) find it was more binding than the risk-based capital standards during the period under study.

Of particular interest in this study is the regulatory pressure variables. Consistent with Shrieves and Dahl (1992), this study uses dummy variables to signify the degree of regulatory pressure that a bank is under. Specifically, the PCA dummies are:

$P C A A=1$ if the bank is adequately capitalized; else $=0$.

PCA U $=1$ if the bank is undercapitalized, substantially undercapitalized, or critically undercapitalized (hereafter referred to as undercapitalized); else $=0$.

These variables allow banks across different PCA zones to respond differently, both in capital ratios and in portfolio risk. A priori, banks in the undercapitalized group, PCA U , would be expected to have the strongest response because PCA imposes penalties on their activities. Furthermore, adequately capitalized banks, PCA A, may increase their capital ratios or reduce their portfolio risk if they perceive a significant penalty for not being considered well capitalized, or if they desire to hold a buffer stock of capital as a cushion against shocks to equity as argued by Wall and Peterson (1987, 1995) and Furlong (1992). Besides being included as a separate variable, PCA is included in an interaction term with the lagged capital ratios. The use of this term allows banks in different PCA zones to have different speeds of adjustment to their target capital ratios. As such, banks in the undercapitalized PCA zones would be expected to adjust their capital ratios at faster rates than better capitalized banks.

Given these variables, equations 3 and 4 can be written:

(5) $\Delta C A P_{j, t}=\delta_{0}+\delta_{1} S_{I Z E_{j, t}}+\delta_{2} B H C_{j, t}+\delta_{3} I N C_{j, t}$ $+\delta_{4} \Delta R I S K_{j, t}+\delta_{5} P C A A+\delta_{6} P C A U$ $-\delta_{7} C A P_{j, t-1}-\delta_{8} P C A A \times C A P_{j, t-1}$ $-\delta_{9} P C A \cup \times C A P_{j, t-1}+\mu_{j, t}$;

(6) $\Delta R I S K_{j, t}=\lambda_{0}+\lambda_{1} S I Z E_{j, t}+\lambda_{2} B H C_{j, t}$ $+\lambda_{3} \Delta C A P_{j, t}+\lambda_{4} R_{I S K}, t-1$ $+\lambda_{5} \mathrm{PCAA}+\lambda_{6} \mathrm{PCAU}+\omega_{\mathrm{j}, \mathrm{t}}$,

where $\mu_{\mathrm{j}, \mathrm{t}}$ and $\omega_{\mathrm{j}, \mathrm{t}}$ are error terms, and $P C A A \times C A P_{j, t-1}$ and PCAU $\times C A P_{j, t-1}$ are interaction terms, which allow a bank's speed of adjustment to be influenced by the PCA zone the bank is in.

\section{EMPIRICAL ESTIMATION}

As noted earlier, the FDICIA was passed in December 1991, with the PCA thresholds becoming effective in December 1992. This study covers the period after passage but before implementation (1992), and the first year the PCA standards were in effect (1993). In addition, because all of the capital ratios used in PCA are availablebeginning at the end of 1990, 1991 is used as a control period. As noted earlier, a significant decline in the number of all types of undercapitalized institutions occurred during the year after FDICIA was passed. This result is not surprising because restrictions would be placed on the activities of these banks beginning in D ecember 1992. Alternatively, in studying the impact of the risk-based capital standards, $H$ aubrich and Wachtel (1993) note that because the composition of bank portfolios can be changed quickly, and 
because banks appear to have experienced a period of learning, the impact appears more clearly after the implementation date. The same argument may be true for PCA, although learning by banks may be less significant with regard to PCA because all of the capital ratios defined in the PCA standards had been in effect since at least December $1990{ }^{7}$

\section{RESULTS}

This study examines 2,552 FDIC-insured commercial banks with assets of $\$ 100$ million or more using year-end call report data from 1990 through $1993 .{ }^{8}$ The model is estimated using the two-stage least squares procedure, which recognizes the endogeneity of both bank capital ratios and risk levels in a simultaneous equation framework, and unlike ordinary least squares, provides consistent parameter estimates.

The results of estimating the simultaneous system of equations 5 and 6 are presented in Tables 2 and 3. Table 2 uses the ratio of risk-weighted assets to total assets (RWA RAT) to measure portfolio risk, while Table 3 measures risk using nonperforming loans as a percentage of total assets (N ON P). All of the variables included to explain variations in capital ratios and risk levels are statistically significant in at least some of the equations. Bank size (SIZE) had a negative and significant impact on capital ratios in two equations, while multibank holding company status (B H C) was consistently negative and significant in the capital equations. Income (IN C) had a positive and significant impact on capital ratios in all equations, suggesting that one reason for increasing capital ratios by banks over the period studied was the increase in their income levels. The parameter estimates on lagged risk $\left(R \mid S K_{j, t-1}\right)$ in the risk equations range from 5.3 percent to 24.7 percent, while the parameter estimates on lagged capital $\left(C \mathrm{P}_{\mathrm{j}, \mathrm{t}-1}\right)$ in the capital equations range from 6.2 percent to 8.9 percent. These results imply that banks

Table2

Tw O-Stage Least Squares Estimates of Prompt Corrective Action on Risk (RWARAT) and Capital

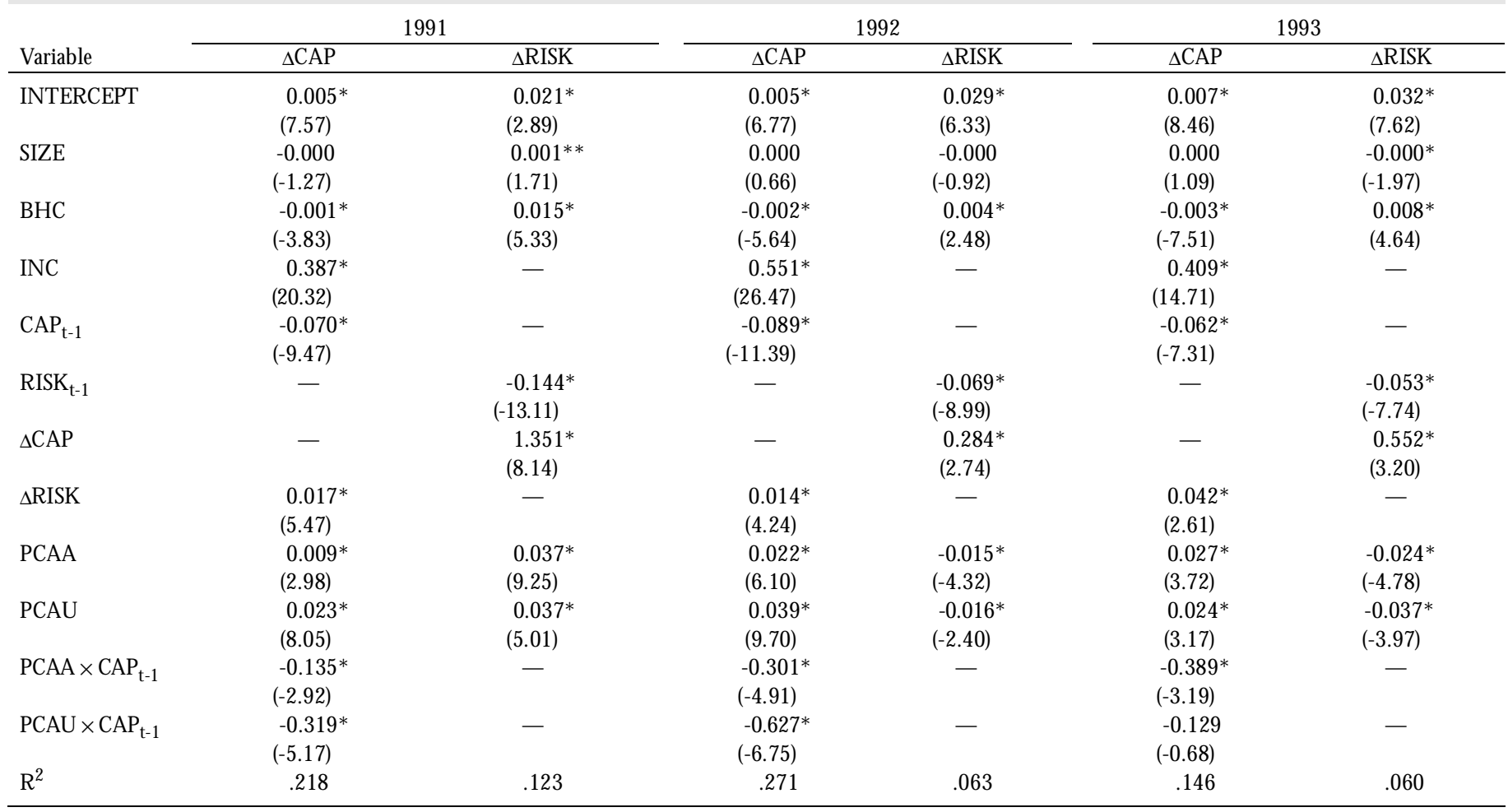

$\mathrm{N}$ ote: t-statistics appear in parentheses.

* Significant at the 5 percent level.

** Significant at the 10 percent level. 
adjusted their capital ratios and risk positions very slowly over this period to their target levels. Finally, Tables 2 and 3 show mixed results in assessing the relationship between changes in capital ratios and changes in risk. W hen portfolio risk was measured using $N O N P$, the changes in capital ratios and risk were negatively correlated, but when portfolio risk was measured using RWARAT, the parameter estimates were positive. Thus, the relationship between changes in capital ratios and changes in risk during this period is not unambiguous. The goal of this study is to clarify this relationship by examining the possible simultaneous impact of the PCA standards on both bank capital ratios and risk levels.

\section{IMPACT OF PCA ON CAPITAL}

In examining the impact of PCA, the results in Tables 2 and 3 provide some rather interesting insights. In the capital equations of each table, the impact of the regulatory pressure variables are captured both by an intercept term ( $P C A A$ or PCAU) and a speed of adjustment term $\left(\mathrm{PCAA} \times \mathrm{CAP}_{\mathrm{t}-1}\right.$ or PCAU $\left.\times \mathrm{CAP}_{\mathrm{t}-1}\right)$. For adequately capitalized banks ( $P C A A$ ), regulatory pressure had a positive impact on capital ratios in both 1992 and 1993, with the parameter estimate in most cases being at least 100 percent larger in 1992 and 1993 than in 1991. Furthermore, the speed of adjustment terms for adequately capitalized banks are statistically significant, being in most cases two to four times greater in 1992 and 1993 than in 1991. Taken together, these results suggest that in both 1992 and 1993, banks classified as being adequately capitalized increased their capital ratios and the speed with which they adjusted their capital ratios in response to PCA. Furthermore, this result is consistent with the hypothesis that banks held capital above the regulatory minimum as a buffer against shocks that could cause their capital ratios to fall bel ow the adequately capitalized thresholds.

Table3

Tw O-Stage Least Squares Estimates of Prompt Corrective Action on Risk (N ON P) and Capital

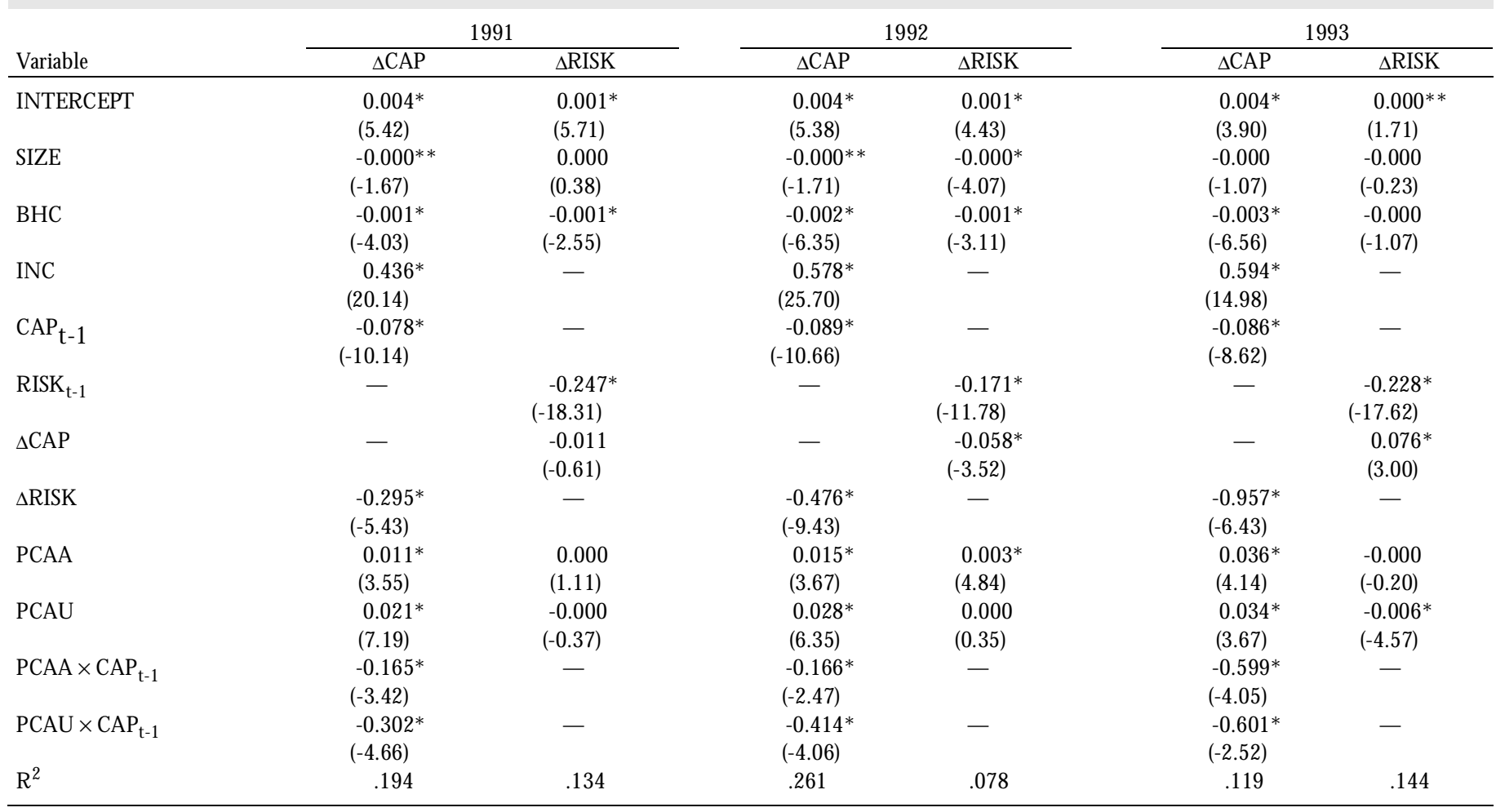

$N$ ote: t-statistics appear in parentheses.

* Significant at the 5 percent level.

** Significant at the 10 percent level. 
The same results appear to hold true for undercapitalized banks ( $P C A U$ ), although the timing and magnitude of the changes appear somewhat different. The parameter estimates on PCAU are significantly different from zero in both 1992 and 1993, and in all cases, they are larger than during the control period. In addition, the speed of adjustment estimates are generally significant and of greater magnitude than during the control period, thereby suggesting that undercapitalized banks adjusted their capital ratios at much faster rates than their well-capitalized counterparts. Examining the results in Table 2, the parameter estimates on PCAU and PCAU $\times \mathrm{CAP}_{\mathrm{t}-1}$ for 1992 are almost twice as large as the estimates for the control period, while the 1993 estimates are similar in magnitude or not significant. These results are not surprising because banks that were classified in one of the three undercapitalized zones at the end of 1991 faced regulatory sanctions if they did not significantly increase their capital ratios by the time the PCA standards went into effect in December 1992.

It is also interesting to compare the parameter estimates on PCA $U$ and PCA A in the capital equations. In general, the estimates on PCAU and PCAU $\times C \mathrm{AP}_{\mathrm{t}-1}$ are larger than similar estimates for adequately capitalized banks in 1992, but not in 1993. This result is also not surprising because undercapitalized banks faced severe restrictions on their activities once PCA went into effect, while adequately capital ized banks did not.

\section{IMPACT OF PCA ON RISK}

$W$ ith respect to portfolio risk, the results in Tables 2 and 3 provide some evidence that the regulatory pressure brought about by PCA led both adequately capitalized and undercapitalized banks to decrease their level of portfolio risk. W hile the results with respect to risk in Table 3 are generally insignificant, when portfolio risk is measured using RWARAT (Table 2), the results suggest that adequately capitalized banks (PCA A) significantly decreased their portfolio risk in both 1992 and 1993, with the parameter estimate for 1993 being 60 percent larger than the estimate for 1992. In a similar manner, the parameter estimates for undercapital ized banks (PCA U ) in Table 2 are negative and significant in both 1992 and 1993, with the parameter estimate for 1993 being more than twice as large as the 1992 estimate. This is in sharp contrast to the results for 1991, where the parameter estimates for both adequately capitalized and undercapitalized banks are positive and significant, thus suggesting that these banks were increasing portfolio risk in the period before FDICIA was passed. For 1992 and 1993, the reduction in risk is not surprising because while PCA was announced in December 1991, sanctions and restrictions on banks became effective at the end of 1992. Therefore, if banks viewed the sanctions associated with PCA as being costly, they had a greater incentive once PCA became effective to reduce their portfolio risk level, and thereby reduce the probability of falling bel ow the capital thresholds due to shocks to equity or income.

Finally, the 1992 parameter estimate on PCAU in Table 2 is almost identical to that on PCA A, a result that suggests that while both types of banks responded to the announcement of PCA by reducing risk, the reduction in risk by undercapital ized banks was not significantly different from that of adequately capitalized institutions. Given the results of the capital equations in Table 2 that undercapitalized banks had larger adjustments to their capital ratios in 1992 than in 1993, and recognizing that undercapitalized banks may be able to adjust their risk levels faster than they can adjust their capital ratios, it is possible that undercapitalized banks emphasized increasing capital rather than reducing risk in 1992. However, in 1993, the parameter estimate on PCA U in the risk equation of Table 2 is over 50 percent greater than the parameter estimate on PCA A. This provides some evidence that undercapitalized banks may have felt even greater pressure than adequately capitalized banks to reduce their level of portfolio risk once the PCA standards became effective.

\section{CONCLUSION}

The purpose of this paper has been to investigate the impact of the PCA standards on bank capital ratios and portfolio risk levels. The results suggest that during both 1992 and 1993, adequately capitalized and undercapitalized banks increased their capital ratios and the rate at 
which they adjusted their capital ratios in response to the PCA standards. In addition, this study finds some evidence that the PCA standards led to significant reductions in portfolio risk, particularly in 1993, the year after PCA took effect. While these results do not guarantee that bank capital levels are adequate relative to the risk in bank portfolios, they do suggest that PCA has been effective in getting banks to simultaneously increase their capital ratios and reduce their level of portfolio risk.

The views expressed in this article are those of the authors and do not necessarily reflect the position of the Federal Reserve Bank of New York or the Federal Reserve System. The Federal Reserve Bank of New York provides no warranty, express or implied, as to the accuracy, timeliness, completeness, merchantability, or fitness for any particular purpose of any information contained in documents produced and provided by the Federal Reserve Bank of New York in any form or manner whatsoever. 


\section{ENDNOTES}

1. In addition, FDICIA authorizes bank regulators to reclassify a bank at a lower capital category if, in the opinion of the bank regulators, the bank is operating in an unsafe or unsound manner.

2. The tangible equity ratio equals the total of Tier 1 capital plus cumulative preferred stock and related surplus less intangibles except qualifying purchased-mortgage-servicing rights divided by the total of bank assets less intangible assets except qual ifying purchased-mortgage servicing rights.

3. For example, see Peek and R osengren $(1996,1997)$.

4. The mean-variance framework has been criticized by some because it fails to incorporate the effects of deposit insurance. See Furlong and K eeley (1989) and K eeley and Furlong (1990).

5. Shrieves and Dahl (1992) note that a positive relationship between changes in capital ratios and portfolio risk may also occur because of regulatory costs, bankruptcy cost avoidance, and managerial risk aversion.
6. Because loans made in a given year will not be recognized as nonperforming until a future period, we follow Shrieves and D ahl (1992) and use nonperforming loans in the following year. Thus, the N ON P variable is the ratio of nonperforming loans to total assets from year-end 1992 through 1994.

7. Finally, a word of caution is necessary because this analysis may be complicated by other factors present during this time period, such as the end of the interim period for implementation of the risk-based capital standards and other provisions of FDICIA, all of which make it difficult to isolate and definitively assess the impact of the PCA provisions. $\mathrm{N}$ evertheless, with the simultaneous assessment of changes in bank capital, portfolio risk, and the regulatory environment, this study is a significant improvement over our prior understanding of the impact of FDICIA, in general, and PCA, in particular.

8. A s noted in endnote6, because of the nature of nonperforming loans, N ON P was cal culated using year-end data from 1992 through 1994. 


\section{REFERENCES}

A very, Robert B., and Allen N. B erger. 1991. "Risk-Based Capital and Deposit Insurance Reform." J OURNAL OF BANKING AND FINANCE 15: 847-74.

B aer, H erbert L ., and J ohn N . M CE Iravey. 1992. "Capital A dequacy and the Growth of U.S. Banks." Federal Reserve Bank of Chicago W orking Paper W P-92-11.

B erger, A llen N. 1995. "The Relationship Between Capital and Earnings in Banking." JOURNAL OF MONEY, CREDIT, AND BAN KING 27: 432-56.

Davies, Sally M., and D ouglas A. M CM anus. 1991. "The Effects of Closure Policies on Bank Risk-Taking." J OURNAL OF BANKING AND FINAN CE 15: 917-38.

Furlong, F rederick T. 1992. "Capital Regulation and Bank Lending." Federal Reserve Bank of San Francisco ECON OMIC REVIEW 3: 23-33.

Furlong, F rederick T., and M ichael C. K eeley. 1989. "Capital Regulation and Bank Risk-Taking: A Note." JOURNAL OF BANKING AND FINANCE 13: 883-91.

H aubrich, Joseph G ., and Paul W achtel. 1993. "Capital Requirements and Shifts in Commercial Bank Portfolios." Federal Reserve Bank of Cleveland ECONOMIC REVIEW 3: 2-15.

J acques, K evin, and Peter N igro. 1997. "R isk-Based Capital, Portfolio Risk, and Bank Capital: A Simultaneous Equations A pproach." J OU RN AL OF ECONOMICS AND BUSINESS 49: 533-47.

Kahane, Y ehuda. 1977. "Capital Adequacy and the Regulation of Financial Intermediaries." J OURNAL OF BANKING AND FINANCE 1: 207-17.

Kane, Edward. 1983. "A Six-Point Program for Deposit-Insurance Reform." HOUSING FINANCE REVIEW 2: 269-78.
K eley, M ichaed C., and F rederick T. Furlong. 1990. "A Reexamination of Mean-Variance A nalysis of Bank Capital Regulation." J OURN AL OF BANKING AND FINANCE 14: 69-84.

Kim, D aesik, and A nthony M. Santomero. 1988. "Risk in Banking and Capital Regulation." J OURN AL OF FIN AN CE 43: 1219-33.

Koehn, M ichael, and A nthony M. Santomero. 1980. "Regulation of Bank Capital and Portfolio Risk." J OURN AL OF FIN AN CE 35: 1235-50.

L evonian, M ark E. 1991. "W hat H appens If Banks A re Closed 'Early'?" In Rebuilding Banking: Proceedings of the 27th Conference on Bank Structure and Competition, 273-95. Federal Reserve Bank of Chicago.

Peek, J oe, and E ric S. Rosengren. 1996. "The U se of Capital Ratios to Trigger Intervention in Problem Banks: T oo Little, T oo Late." Federal Reserve Bank of Boston NEW ENGLAND ECONOMIC REVIEW, September-October: 49-58.

- - . 1997. "W ill Legislated Early Intervention Prevent the N ext Banking Crisis?" SOUthern ECon Omic Review 64: 268-80.

Shrieves, R onald E., and D rew D ahl. 1992. "The Relationship Between Risk and Capital in Commercial Banks." J OURNAL OF BAN KIN G AND FINANCE 16: 439-57.

W all, Larry D., and David R. Peterson. 1987. "The Effect of Capital A dequacy Guidel ines on Large Bank H ol ding Companies." J OURNAL OF BANKING AND FINANCE 11: 581-600.

- - . 1995. "Bank H olding Company Capital Targets in the Early 1990s: The Regulators Versus the Market." J OURNAL OF BANKING AND FINANCE 19: 563-74. 